\title{
Trait Based Assessment on Teaching Writing Skill for EFL Learners
}

\author{
Maman Asrobi ${ }^{1} \&$ Ari Prasetyaningrum ${ }^{1}$ \\ ${ }^{1}$ Hamzanwadi University, Indonesia \\ Correspondence: Maman Asrobi, Hamzanwadi University, Indonesia. E-mail: mmnasrobi@gmail.com
}

Received: August 27, 2017 Accepted: October 15, 2017 Online Published: October 19, 2017

doi: 10.5539/elt.v10n11p199 URL: http://doi.org/10.5539/elt.v10n11p199

\begin{abstract}
This study was conducted in order to investigate the effectiveness of trait based assessment on teaching writing skill for EFL learners. Designed as pre-experimental study with one group pretest and posttest design, it examined 20 students of the second semester of English Department of Hamzanwadi University in the academic year 2016/ 2017 as the samples. Purposive sampling technique was used in determining the samples. Writing test and analytical scoring rubric were the instruments used to collect the data. Then the data were analyzed by using descriptive statistics and paired sample t-test to test the hypothesis. The result of descriptive statistics analysis revealed that trait based assessment is effective on teaching writing skill for EFL learners since the mean score of posttest 60 was higher than mean score of pretest 28.20. While for hypothesis testing by using paired sample t-test at significance (2-tailed) value level was .000, it was lower than .05. Therefore, it means that the hypothesis of this study was accepted. In other word, trait based assessment was significantly effective in improving students' writing skill.
\end{abstract}

Keywords: writing skill, trait-based assessment

\section{Introduction}

Writing is the least popular language skill and most students consider writing is the least useful or necessary for them to be mastered. This is due to their assumption that writing has very little advantages for them in real life. However, they may miss that the skill of writing has special status in language skill. It is via writing a person can communicate a variety of massages to a close or distant, known or unknown reader (Murcia, 2001).

Most EFL learners might agree when we say that writing is the most difficult skills for them to be mastered. The difficulty lies not only in generating and organizing ideas but also in translating these ideas into readable text and understandable. The skills involved in writing are highly complex. Brown (2001) and Hatta (2009) see that EFL writers have to pay attention to higher level skills of planning and organizing as well as lower skills of spelling, punctuation, word choice, accuracy, i.e. using the correct forms of language. Writing accurately involves spelling correctly, forming letters correctly, writing legibly, punctuating correctly, using correct layouts, choosing the right vocabulary, using grammar correctly, joining sentences correctly and using paragraphs correctly. The difficulty then becomes more pronounced if their language proficiency is weak.

However, the need for hard work in writing should not be simply interpreted that more and more practice is further expected because a lot of practices in writing without any feedback do not always a guarantee of successful outcomes (Gere, 1992; McCrimmon, 1984). This view is approved by the result of the study held by Latief (1990) that showed the students' low paragraph quality, despite the numerous exercises on writing paragraphs and grammatical courses. Thus, hard work and plenty of exercises in writing must be completed with awareness that writing should be thought and assessed in an efficient way.

In accordance with the view that writing is a difficult skill to be mastered, the results of the preliminary observation were conducted to the students who take writing for general communication class in Hamzanwadi University showed that they had poor skills in writing recount text. Their problems covered the following aspects: (1) creating completeness, (2) formulating the claim/ proposition, (3) maintaining unity, (4) keeping coherence, (5) diction, and (6) grammar and mechanics. Besides, the students were observed to have poor habits of writing, as they were not used to writing regularly instead of fulfilling the assignments given by the teacher. They were observed that they did not consider seriously what to write and how to write the ideas as they concerned most on finishing their papers. As an addition, they were also observed to have poor participation and unconfident to their writing. 
Through the preliminary observation, it was also discovered that the writing practice was emphasized on the end result or product based writing without any feedback to the students about their writing. During the writing practice, the lecture firstly introduced the concept or pattern of writing that was going to be practiced in the class. After the concepts were clear, he gave the students a model paragraph to be discussed usually in terms of the development and organization of the ideas, the shift of the ideas, grammar and mechanics. Then, he asked the students to write paragraphs of the same kind of pattern. Finally, the paragraphs were collected for grading. These activities failed to improve the students' ability in writing skill.

However, several solutions can be proposed in order to improve the students' skills in writing. One solution is by using an assessment. Assessment is an important component in teaching writing skill. Here, to improve the quality of students' writing ability can be reached not only through improving the quality of teaching but also through the quality of assessment. Assessment in writing skills needs to be done professionally and appropriately, so that the teacher is able to diagnoses the weaknesses and strengths of the students in writing. So, the result of writing assessment can be used as a basis for making decisions in the teaching writing process in order to achieve the teaching and learning process more optimal. This is the idea to put forward by trait based assessment that tries to analyze and diagnoses the students' weaknesses and strengths more detail about their writing. Thus, it is expected that they can improve their writing skill after solve their weaknesses and develop their strengths.

Dahl and Farnan (1998) state that as an assessment, trait based assessment offers the most proper information because each elements in writing is assessed separately by every characteristics marked with scales which show how good the texts are produced. Then, trait based assessment enables objective measurement and assist teachers to decide which parts of the students' writing must be improved (Steineger, 1996). As an addition, by assessing students' writing separately, a teacher could provide positive feedback to the parts which the students understand (Isernhagen \& Kozisek, 2000).

Based on the complex difficulty faced by the learner in learning writing skill, this study attempts to investigate the effectiveness of trait based assessment on teaching writing skill. Based on the illustration above, the researcher is quite sure that trait based assessment can meet the challenges and weakness of EFL learners' writing ability and may improve it. Thus, the results of this study provide (1) the descriptions of the model of trait based assessment that can improve the students' skills in writing recount text, (2) the descriptions of the students' performance after the implementation of trait based assessment and (3) the descriptions of the students' responses to the implementation of trait based assessment.

\section{Method}

This study used pre-experimental with pretest-posttest design since this study concerns with investigating the effectiveness of trait based assessment on teaching writing skill for EFL learners. Even though there were 102 students altogether in the writing for general communication class of the English Department of Hamzanwadi University in the academic year 2016/2017, only twenty of them were selected as the subjects of the study. This decision was made in order to allow the researcher to make a detailed observation and assessment on the students' performance and on the teaching and learning process, which further allow them to make a detailed analysis of the results of the observation and assessment. As an addition, the twenty selected students were those who were considered to perform the poorest in the writing class, particularly in composing recount text.

To obtain the data, the researcher used writing test in form of essay test and the scoring system was determined by an analytical scoring rubric. The criteria of evaluation used the scale (1-5) by Brown (2007) in which writing ability was valued from 5 variables, namely: content, organization, grammar, vocabulary, and mechanics.

Then, the data obtained from pretest and posttest were analyzed using descriptive statistics and paired-sample t-test to test the hypothesis. Based on the result of data analysis, the highest score on pre-test was 36 and the lowest score was 24 . While, on post-test, the highest score was 72 and the lowest score was 52 . In addition, the mean score of pre-test was 28.20 and standard deviation was 3.995, meanwhile the mean score of post-test was 60.00 and standard deviation was 6.358 .

Meanwhile, for the hypothesis testing by using paired sample t-test, the researcher determined the confidence interval of the difference was $95 \%$ and the standard significance (2-tailed) value level was .05 . The result of paired sample t-test showed that the sig (2-tailed) is much lower (.000) than .05 , it means that the hypothesis of this study is accepted. So, trait based assessemnt is significantly effective on teaching writing skill for EFL learners.

\section{Findings}

The preliminary observation on pretest confirmed that most of the students had problems in writing recount text 
in terms of content, organization, grammar, vocabulary, and mechanics. From 20 subjects under studied, the result of pre-test proved that they have problems in writing ability. The data showed that their writing ability before accepted treatment was at level of "very poor" it can be seen from the mean score obtained (20.28) that was categorized into "very poor". Detailed data on students' achievement in pre-test can be shown as follows: 18 students (90\%) fall into category of "very poor", and 2 students $(10 \%)$ were categorized as "poor", and no one of the students achieved category of sufficient, high, and very high. Therefore, from the above data it can be concluded that all of the samples (100\%) still have problems in writing ability and they need to be helped to improve their writing ability.

The result of students' writing provides clear descriptions of the problems encountered by the students in writing recount text. Besides, it was also observed that they did not have good writing habits and were not well motivated to do their writing activities.

The findings showed that the assessing activity using trait based assessment was in general good and smooth, since the researchers could carry out the writing practice on the basis of the already developed plans. In carrying out the practice, the researchers employed the steps, such as (1) Prewriting, which covers making a discussion of what recount text is, making a discussion of what trait based assessment is, selecting a subject to write, determining the audience and determining the purpose; (2) Planning, that is through brainstorming; (3) Drafting, which covers drafting a scratch outline, the hypothesis, a discovery draft, a descriptive outline and the formal outline; (4) Revising, which covers the sharing for global and proofreading for local revision; (5) Writing the paragraph; and (6) Evaluation.

In addition, the post-test results further demonstrated that their writing ability improved significantly, it can be proved with a total mean score 60 that categorized into "average". Detailed data on students in the posttest can be displayed as follows: 0 students $(0 \%)$ that goes into the category of "very poor", 13 students $(56 \%)$ obtained a score of 56-64 and categorized into "average", 3 students (10\%) obtained a score of 68-72 and categorized in the "good", and 0 students (\%) categorized into "very good". Therefore, from the above data it can be concluded that the majority of students $16(73.09 \%)$ have achieved an "average" category on their writing ability.

Table 1. Detail number of errors on students' writing

\begin{tabular}{lllll}
\hline \multirow{2}{*}{ Aspect } & $\begin{array}{l}\text { Pre-Test } \\
\text { Total Error }\end{array}$ & Percentage & $\begin{array}{l}\text { Post-test } \\
\text { Total Error }\end{array}$ & Percentage \\
\hline Contents & 81 & $13 \%$ & 28 & $9 \%$ \\
Organization & 65 & $10 \%$ & 29 & $10 \%$ \\
Grammar & 246 & $38 \%$ & 100 & $33 \%$ \\
Vocabulary & 160 & $25 \%$ & 102 & $33 \%$ \\
Mechanics & 89 & $14 \%$ & 44 & $15 \%$ \\
Total & $\mathbf{6 4 1}$ & $\mathbf{1 0 0}$ & $\mathbf{3 0 3}$ & $\mathbf{1 0 0}$ \\
\hline
\end{tabular}

The subjects' skills showed improvement in the post test as shown on their evaluated writing papers. They could select the subjects to write, decide their audience, determine their purpose, draft their paragraphs, revise them and at last rewrite them. Table 02 verified that their writings improved in terms of completeness, topic sentence, unity, coherence, diction, grammar and mechanics.

The students' responses in teaching and learning activities were positive, as they participated in the teaching and learning activities well, paid attention on the teacher-researcher's explanation closely and did the instructions given to them enthusiastically. They also admitted that they were happy in joining the class.

\section{Discussion}

The result of this study revealed that trait based assessment was significantly effective on teaching writing skill for EFL learners. This type of assessment is significantly effective because the information on learning progress was collected in detail and comprehensively in an enjoyable athmosphere, and always offer opportunity for students to show not only what they know, understand and what they can do but also the problems and difficulties which they often face in learning writing.

In writing skill, students are demanded to be able to explore and to motivate themselves to produce their ability 
in responding, and solving all problems they found. By applying trait based assessment, those things can be done since students and teacher discuss about their texts directly. In discussion process, a teacher could provide suggestion and motivation on students' writing detail and comprehensively.

In addition, by applying trait based assessment, students' learning achievement was not be compared to the group progress, but it was compared to the prior ability, so the students were motivated to revise their errors and improve their writing quality. In other word, trait based assessment helped the students to achieve what they wanted, instead of to judging them. Trait based assessment was also very effective to determine whethet there was learning progress or not and whether planned and on going assistance was needed or not, based on accurate facts or proofs.

Furthermore, by applying trait based assessment the teachers could improve learning system based on students' need because during learning process with trait based assessment, a teacher could know well what the students need to make their writing better. Having conducted trait based assesment, scoring and discussion result by the studenst offered suggestion for the teachers to improve learning program in the classroom.

\section{Conclusions and Suggestions}

On the basis of the above discussions, it is concluded that (1) the effective model of trait based assessment that can improve the students' skills in writing argumentative paragraphs consists of six main activities described in the discussion section; (2) the students' performance in writing argumentative paragraphs can be improved, as they can write with completeness, good and effective formulation of claim, good unity, good coherence, appropriate diction, and correct grammar and mechanics; and (3) the students were happy and joined the writing class actively, as they could master process approach well and get seriously involved in the teaching and learning process.

Finally, it is suggested to (1) the lectures-researcher and the other writing instructors in Hamzanwadi University to adopt or to consider the model of trait based assessment developed in this study in order to teach the students writing or to improve their writing skills; (2) other lectures-researchers that might be interested in the results of this study to see trait based assessment to teaching writing and the model of trait based assessment developed in this study as another possibility or alternative that requires deep consideration in conducting their study.

\section{References}

Arnaudet, M. L., \& Mary E. B. (1990). Paragraph Development: A Guide for Students of English. New Jersey: Prentice Hall Regent.

Basuki, Imam, Agus. (2012). Pengaruh Penilaian Sejawat Dalam Pembelajaran Menulis Terhadap Kualitas Karangan Siswa Madrasah Tsanawiyah. Jurnal Pendidikan dan Pembelajaran, 19(1).

Brereton, J, C. (1982). A Plan for Writing. New York: Holt, Rinehart and Winston.

Dahl, K., \& Farnan, N. (1998). Children's Writing: Perspectives from Research. Newark, DE:. International Reading Association .

Dueraman, B. (2015). The Crucial Point in Time Where Thai Students Are Introduced English Language Writing. English Language Teaching, 8(9). http://dx.doi.org/10.5539/elt.v8n9p96

Gay, L. R., Mills, G. E., \& Airasian, P. W. (2009). Educational Research: Competencies for Analysis and Applications. (Ninth Edition). Ney Jersey: Pearson Education, Inc.

Gere, A, R. (1992). Writing and Learning. New York: Macmillan Publishing Company.

Jodaie, M. (2011). A Comparative Study of EFL Teachers' and Intermediate High School Students' Perceptions of Written Corrective Feedback on Grammatical Errors. English Language Teaching, 4(4). http://dx.doi.org/10.5539/elt.v4n4p36

Latief, M. A. (1990). Assessment of English Writing Skills for Students of English as a Second Language at IKIP Malang Indonesia. Unpublished Ph.D Dissertation. Iowa: Iowa University.

Moedjito. (2014). Basic Statistic for Research in Language Education. Unpublished Modul: STKIP Hamzanwadi Selong, Nusa Tenggara Barat, Indonesia.

Nguyen, H. T. (2016). Peer Feedback Practice in EFL Tertiary Writing Classes. English Language Teaching, 9(6). http://dx.doi.org/10.5539/elt.v9n6p76

Sundem, G. M. M. (2006). Practical Strategies for Successful Classrooms: Improving Student Writing Skills. USA. Shell Education. 
Syakur. (1987). Language Testing and Evaluation. Surakarta: Sebelas Maret University Press.

Tabatabaei, O. (2012). The Effect of Portfolio Assessment Technique on Writing Performance of EFL Learners. English Language Teaching, 5(5). http://dx.doi.org/10.5539/elt.v5n5p138

\section{Copyrights}

Copyright for this article is retained by the author(s), with first publication rights granted to the journal.

This is an open-access article distributed under the terms and conditions of the Creative Commons Attribution license (http://creativecommons.org/licenses/by/4.0/). 